\title{
Variability in Puccinia melanocephala Pathogenicity and Resistance in Sugarcane Cultivars
}

J. W. Hoy, M. C. Avellaneda, and J. Bombecini, Department of Plant Pathology and Crop Physiology, Louisiana State University Agricultural Center, Baton Rouge 70803

\begin{abstract}
Hoy, J. W., Avellaneda, M. C., and Bombecini, J. 2014. Variability in Puccinia melanocephala pathogenicity and resistance in sugarcane cultivars. Plant Dis. 98:1728-1732.

Brown rust, caused by Puccinia melanocephala, is an important disease of sugarcane worldwide, controlled primarily with host plant resistance. Disease response shifts from resistant to susceptible have been repeatedly observed for cultivars. However, information is limited concerning pathogen variability related to host reactions. To evaluate variability in the pathogen population and characterize resistance responses in different host genotypes, seven cultivars were inoculated with four urediniospore collections from three cultivars. Greenhousegrown plants were inoculated under controlled conditions favorable for infection and disease development. Severity assessed as leaf area occupied by lesions, lesion density, and lesion size was determined and

compared. Three cultivars that shifted from resistance to high susceptibility while under cultivation exhibited differential disease severity when inoculated with spore collections from two of the respective cultivars. Two cultivars exhibited consistent moderate to high levels of quantitative resistance against all spore collections and two cultivars, including one with the Bru1 resistance gene, were highly resistant to all collections. Differential reactions were best revealed by assessing percent leaf area. Pathogenic variability related to host genotype was confirmed, and quantitative resistance was detected that could be useful to improve breeding and selection for effective, durable resistance to brown rust.
\end{abstract}

Brown rust is an economically important disease in many regions where sugarcane is grown (18). The primary control measure is the development and cultivation of resistant cultivars. However, the durability of resistance to brown rust is uncertain because the pathogen, Puccinia melanocephala Syd. \& P. Syd., possesses the ability to adapt and overcome host plant resistance. Shifts from resistance to susceptibility have been reported for cultivars in different regions $(6,11,15,17)$, and these shifts have been suggested to be due to pathogenic specialization. Three studies have compared differential reactions resulting from inoculation. In Australia, it was concluded that specialization within the pathogen population to cultivar was not evident (22) but studies in Florida (19) and India (20) found differential reactions in cultivars inoculated with pathogen isolates from the same cultivars.

In Louisiana, when the proportion of the area cultivated with 'LCP 85-384' increased to over 40\%, a severe epidemic of brown rust occurred in what had previously been rated as a resistant cultivar (11). Subsequently, two additional cultivars, 'Ho 95-988' and 'HoCP 96-540', shifted from resistant to highly susceptible ratings (J. W. Hoy, unpublished). However, these field observations have provided only indirect evidence of changes in pathogenicity within the $P$. melanocephala population related to host genotype in Louisiana.

Some studies of the genetics of brown rust resistance in the host have been made. Modern sugarcane cultivars are interspecific hybrids that contain 100 to 120 chromosomes, with approximately $80 \%$ of the genome contributed by Saccharum officinarum $(2 \mathrm{n}=$ $80), 10$ to $15 \%$ by $S$. spontaneum $(2 \mathrm{n}=48$ to 124$)$, and 5 to $10 \%$ from recombination between the two species $(7,14)$. Sugarcane is an aneu-polyploid, and the genome complexity has hindered classical and molecular genetic studies of the crop. Many traits in sugarcane are quantitatively expressed, and resistance to brown

Corresponding author: J. W. Hoy, E-mail: jhoy@ agcenter.lsu.edu

Accepted for publication 10 June 2014.

http://dx.doi.org/10.1094/PDIS-01-14-0074-RE

(C) 2014 The American Phytopathological Society rust is known to be polygenic in nature $(10,12,21)$. Two resistance genes for brown rust, Bru1 and Bru2, have been reported $(5,16)$ Breeding programs apparently have unknowingly selected for Bru 1 $(4,8)$, and resistance in some industries may rely heavily on this gene that has shown to be effective against geographically diverse P. melanocephala populations (1). The evaluation of resistance has generally relied on rating the severity of natural infection.

Brown rust has become the most important disease affecting sugarcane in Louisiana due to the lack of resistance durability. The purpose of this study was to evaluate pathogenic variability in the current pathogen population and also characterize resistance responses in different host genotypes.

\section{Materials and Methods}

Four sugarcane cultivars susceptible to brown rust (LCP 85-384, Ho 95-988, HoCP 96-540, and 'L 99-226') and three cultivars currently rated as resistant ('L 99-233', 'L 01-283', and ' $\mathrm{L}$ 01299'), based on observation of natural infection severity, were included. The susceptible cultivars were rated as resistant when released. LCP 85-384 was the male parent for HoCP 96-540, L 01283, and L 01-299.

Plants were started in the greenhouse from single-node cuttings and grown until three to four leaves had emerged. Individual plants were then inoculated under controlled conditions (2) with one of four different urediniospore collections from three cultivars: Ho 95-988 (two collections from fields in different areas), HoCP 96540, and L 99-226. Urediniospores were collected by vacuum from the abaxial surface of multiple naturally infected leaves in single fields and stored at $-80^{\circ} \mathrm{C}$.

Three plants of each cultivar were inoculated with a urediniospore concentration of approximately $1 \times 10^{6}$ urediniospores $/ \mathrm{ml}$ (determined with a hemacytometer) suspended in distilled water with $0.1 \%$ Tween 20 . Inoculum was applied to both sides of two fully emerged leaves per plant with a small brush to create three replicates per host-pathogen combination. Urediniospore suspensions were brushed onto the surface of water agar plates at the time of inoculation, and the germination frequencies (percent) for individual collections were determined by microscopic examination the next morning in two experiments. Inoculated plants were placed for $15 \mathrm{~h}$ in an indoor plastic mist chamber maintained at a 
temperature of $23 \pm 1^{\circ} \mathrm{C}$. Additional distilled water was applied to leaves with an atomizer; then, cool mist generators were used to create high relative humidity and maintain leaf wetness for the entire $15 \mathrm{~h}$. After the infection period, the plants were kept under artificial lighting at $23 \pm 1{ }^{\circ} \mathrm{C}$. The experiment was performed twice in September and December 2012.

Two weeks after inoculation, the percentage of leaf area occupied by lesions and lesion density (lesion number per square centimeter) were determined for each inoculated leaf using Assess 2.0 Image Analysis Software (American Phytopathological Society). Individual lesion size (in square millimeters) was calculated by dividing total leaf area by the number of lesions per leaf. Data for percent leaf area with lesions (arcsin transformed), lesion density, and lesion size were analyzed using Proc GLM (SAS version 9.3) to evaluate the effects of cultivar, urediniospore source, experiment, and interactions. Disease severity means were compared within experiments by Fisher's least significant difference test.

\section{Results}

In a combined analysis of all data from both experiments (results not shown), percent leaf area and lesion density were highly significantly affected by cultivar and spore source while lesion size was not significantly affected by either variable. However, experiment had a highly significant effect on all three disease traits. Significant interactions were detected for all two-way interactions, except for spore source-experiment, and the three-way interaction cultivar-spore source-experiment for percent leaf area. All interactions were significant for lesion density. For lesion size, the cultivar-spore source interaction was highly significant, the three-way interaction was significant, and the cultivar-experiment and spore source-experiment interactions were not significant. The significant experiment factor and interactions indicated that a separate analysis of the two experiments was appropriate.

Percent leaf area. The leaf area occupied by lesions ranged across cultivars and spore collections from 0.05 to $9.40 \%$ in experi- ment 1 (Table 1), and 0.03 to $4.11 \%$ in experiment 2 (Table 2). Urediniospore germination frequencies on water agar were 30,26 , 22, and $31 \%$ for collections 1 (Ho 95-988-1), 2 (Ho 95-988-2), 3 (HoCP 96-540), and 4 (L 99-226), respectively, in experiment 1; and $25,26,14$, and $27 \%$, respectively, for the same four collections in experiment 2. Three susceptible cultivars (LCP 85-384, Ho 95988, and HoCP 96-540) that exhibit severe natural infection in commercial fields showed the most severe infection across urediniospore collections in the two inoculation experiments, with LCP 85-384 showing lower severity in experiment 2 in relation to the other susceptible cultivars (Tables 1 and 2). Susceptible L 99-226 that exhibits moderate to severe natural infection showed moderate disease severity across spore collections. Moderate to low severity resulted from inoculation with all collections for resistant L 99233, with the lowest severity exhibited across spore collections for L 01-283 and L 01-299.

The two spore collections from Ho 95-988 showed similar but not identical infection severities across cultivars in the two experiments. In experiment 1 , severities for L 99-233 and LCP 85-384 were reversed between the two collections (Table 1). In experiment 2, collection Ho 95-988-1 caused less disease on plants of Ho 95988, and spores from HoCP 96-540 caused less disease on LCP 85384 (Table 2). Infection severities were similar across cultivars for all four collections, except that the L 99-226 spore collection caused a lower infection severity across cultivars in experiment 2 . Overall, disease severity assessed as percent leaf area was higher in experiment 1 than experiment 2 (Table 2).

The spore collections from Ho 95-988 and HoCP 96-540 caused differential reactions when inoculated to the respective cultivars in experiment 1 (Table 1), but the reactions were not as pronounced in experiment 2 (Table 2). The same differential reaction was evident for the Ho 95-988 and HoCP 96-540 collections with LCP 85-384, the male parent of HoCP 96-540, in experiment 1 and for the Ho 95-988 collections in experiment 2 . The collection from L 99-226 showed a similar differential reaction pattern across the susceptible

Table 1. Comparison of infection severity assessed as percent leaf area occupied by lesions in seven sugarcane cultivars resulting from inoculation under controlled conditions with four Puccinia melanocephala urediniospore collections from three cultivars in experiment 1

\begin{tabular}{|c|c|c|c|c|c|}
\hline \multirow[b]{2}{*}{ Cultivar inoculated } & \multicolumn{5}{|c|}{ Lesion leaf area $(\%)$ for four urediniospore collections ${ }^{\mathrm{Z}}$} \\
\hline & Collection 1 (Ho95-988-1) & Collection 2 (Ho95-988-2) & Collection 3 (HoCP96-540) & Collection 4 (L99-226) & Mean \\
\hline LCP85-384 & $0.49 \mathrm{~b}$ & $1.49 \mathrm{~b}$ & $9.40 \mathrm{a}$ & $2.36 \mathrm{a}$ & $3.43 \mathrm{AB}$ \\
\hline Но95-988 & $8.68 \mathrm{a}$ & $8.38 \mathrm{a}$ & $0.70 \mathrm{c}$ & $0.24 \mathrm{~b}$ & $4.50 \mathrm{~A}$ \\
\hline НоСР96-540 & $0.64 \mathrm{~b}$ & $0.84 \mathrm{~b}$ & $3.14 \mathrm{~b}$ & $2.75 \mathrm{a}$ & $1.84 \mathrm{BC}$ \\
\hline L99-226 & $1.12 \mathrm{~b}$ & $1.22 \mathrm{~b}$ & $2.47 \mathrm{~b}$ & $1.20 \mathrm{ab}$ & $1.50 \mathrm{BC}$ \\
\hline L99-233 & $1.43 \mathrm{~b}$ & $0.56 \mathrm{~b}$ & $0.16 \mathrm{c}$ & $0.13 \mathrm{~b}$ & $0.49 \mathrm{C}$ \\
\hline L01-283 & $0.51 \mathrm{~b}$ & $0.07 \mathrm{~b}$ & $0.41 \mathrm{c}$ & $0.07 \mathrm{~b}$ & $0.27 \mathrm{C}$ \\
\hline L01-299 & $0.17 \mathrm{~b}$ & $0.07 \mathrm{~b}$ & $0.21 \mathrm{c}$ & $0.05 \mathrm{~b}$ & $0.12 \mathrm{C}$ \\
\hline Mean & $1.89 \mathrm{~A}$ & $1.80 \mathrm{~A}$ & $2.35 \mathrm{~A}$ & $0.97 \mathrm{~A}$ & $\ldots$ \\
\hline
\end{tabular}

${ }^{\mathrm{z}}$ Percentage of leaf area occupied by brown rust lesions following inoculation with each of four urediniospore collections. The cultivar from which spores were collected is shown in parentheses; there were two different spore collections from Ho 95-988. Cultivar means within a column followed by different lowercase letters were significantly different and overall means within spore collections and across cultivars followed by different uppercase letters were significantly different as determined by Fisher's least significant difference test $(P=0.05)$.

Table 2. Comparison of infection severity assessed as leaf area occupied by lesions in seven sugarcane cultivars resulting from inoculation under controlled conditions with four Puccinia melanocephala urediniospore collections from three cultivars in experiment 2

Lesion leaf area $(\%)$ for four urediniospore collections ${ }^{\mathrm{z}}$

\begin{tabular}{|c|c|c|c|c|c|}
\hline Cultivar inoculated & Collection 1 (Ho95-988-1) & Collection 2 (Ho95-988-2) & Collection 3 (HoCP96-540) & Collection 4 (L99-226) & Mean \\
\hline LCP85-384 & $0.35 b c$ & $0.21 b c$ & $0.85 \mathrm{bcd}$ & $0.33 \mathrm{a}$ & $0.43 \mathrm{CD}$ \\
\hline Но95-988 & $1.19 \mathrm{a}$ & $4.11 \mathrm{a}$ & $1.86 \mathrm{~b}$ & $0.13 b c$ & $1.82 \mathrm{~A}$ \\
\hline НоСР96-540 & $1.27 \mathrm{a}$ & $1.26 \mathrm{~b}$ & $2.91 \mathrm{a}$ & $0.12 b c$ & $1.39 \mathrm{AB}$ \\
\hline L99-226 & $0.66 \mathrm{~b}$ & $1.24 \mathrm{~b}$ & $1.16 \mathrm{bc}$ & $0.23 \mathrm{ab}$ & $0.82 \mathrm{BC}$ \\
\hline L99-233 & $0.18 \mathrm{c}$ & $0.38 \mathrm{bc}$ & $0.82 \mathrm{~cd}$ & $0.07 \mathrm{bc}$ & $0.36 \mathrm{CD}$ \\
\hline L01-283 & $0.04 \mathrm{c}$ & $0.06 \mathrm{c}$ & $0.17 \mathrm{~cd}$ & $0.03 \mathrm{c}$ & $0.08 \mathrm{D}$ \\
\hline L01-299 & $0.05 \mathrm{c}$ & $0.04 \mathrm{c}$ & $0.06 \mathrm{~d}$ & $0.06 \mathrm{bc}$ & $0.05 \mathrm{D}$ \\
\hline Mean & $0.54 \mathrm{AB}$ & $1.04 \mathrm{~A}$ & $1.12 \mathrm{~A}$ & $0.14 \mathrm{~B}$ & $\ldots$ \\
\hline
\end{tabular}

${ }^{\mathrm{z}}$ Percentage of leaf area occupied by brown rust lesions following inoculation with each of four urediniospore collections. The cultivar from which spores were collected is shown in parentheses; there were two different spore collections from Ho 95-988. Cultivar means within a column followed by different lowercase letters were significantly different and overall means within spore collections and across cultivars followed by different uppercase letters were significantly different as determined by Fisher's least significant difference test $(P=0.05)$. 
cultivars to the collection from HoCP 96-540, although with lower severity.

Lesion density. The number of lesions per square centimeter of inoculated leaf exhibited a similar overall range in the two experiments, from 0.1 to $7.8 \%$ in experiment 1 (Table 3) and 0.1 to $10.8 \%$ in experiment 2 (Table 4). Cultivar reactions across urediniospore collections were similar to severity assessed as leaf area occupied by lesions. Susceptible LCP 85-384, Ho 95-988, and HoCP 96-540 exhibited the highest lesion density; L 99-226 showed moderate to high severity; and resistant L 99-233, L 01283, and L 99-299 showed generally lower severity in both experiments. Severities assessed as lesion density induced by different urediniospore collections across cultivars were similar to the results for percent leaf area, with all collections alike in experiment 1 but lower severity for the L 99-226 collection in experiment 2 .

Differential reactions for urediniospore collections from the three cultivars were generally similar to those observed for percent leaf area in both experiments (Tables 3 and 4). The expected differential reactions for Ho 95-988 and HoCP 96-540 collections and plants were strongly evident in experiment 1 (Table 3 ). In experiment 2, spore collections Ho 95-988-1 and Ho 95-988-2 caused more disease in HoCP 96-540 and L 99-226, respectively, and the susceptible cultivars could not be distinguished by severity differences for the spore collections from HoCP 96-540 and L 99-226 (Table 4).

Lesion size. Individual lesion size ranged from 0.4 to $1.2 \mathrm{~mm}^{2}$ in experiment 1 (Table 5) and from 0.1 to $1.9 \mathrm{~mm}^{2}$ in experiment 2 (Table 6). Lesion size across collections and cultivars was uniformly numerically higher in experiment 1 than in experiment 2 . Low variation in lesion size resulted in fewer and variable differences among collections and cultivars. The cultivar differential reactions detected by percent leaf area and lesion density assessments were not evident for lesion size, and the susceptible and resistant cultivars were generally not distinguished (Tables 5 and
6). Lesions in Ho 95-988 were larger than in L 99-226, L 99-233, and L 01-283 in experiment 1, and lesions were larger in L 99-233 than L 01-283 in experiment 2. Overall, no consistent patterns were evident for lesion size.

\section{Discussion}

Phenotypic changes of large magnitude from highly resistant to highly susceptible have been observed repeatedly for sugarcane cultivars in diverse geographic areas $(6,11,15,17,18)$. Three studies have experimentally addressed $P$. melanocephala specialization to host genotype. The studies in Florida (19) and India (20) indicated pathogenic variability related to host genotype while one study in Australia did not (22). The urediniospore collections from three different cultivars included in this study were collected in bulk and, therefore, were certainly genetic mixtures, and all four populations caused infection of varying degrees of severity in all susceptible cultivars. The similar reactions by the two urediniospore collections from the same cultivar, Ho 95-988, suggest that the variability in severity caused by different collections was cultivar related, and the evidence for differential host-pathogen reactions that was detected confirms pathogen specialization or adaptation to cultivar level in this pathosystem.

The disease severity results for percent leaf area and lesion density provided evidence for differential and quantitative host reactions in both experiments but most strongly in experiment 1, when severity was higher. Fewer differential reactions were detected for severity assessed as lesion density than for percent leaf area even though the ranges in lesion density were similar between experiments. Lesion size exhibited low variation across spore collections and cultivars and was not consistent between experiments. This trait also had lower severity, similar to percent leaf area in the second experiment. Considered altogether, the results suggest that percent leaf area is the best disease trait for comparative studies of resistance in inoculation experiments.

Table 3. Comparison of infection severity assessed as lesion density in seven sugarcane cultivars resulting from inoculation under controlled conditions with four Puccinia melanocephala urediniospore collections from three cultivars from experiment 1

\begin{tabular}{|c|c|c|c|c|c|}
\hline \multirow[b]{2}{*}{ Cultivar inoculated } & \multicolumn{5}{|c|}{ Lesion density for four urediniospore collections ${ }^{\mathrm{z}}$} \\
\hline & Collection 1 (Ho95-988-1) & Collection 2 (Ho95-988-2) & Collection 3 (HoCP96-540) & Collection 4 (L99-226) & Mean \\
\hline LCP85-384 & $1.3 \mathrm{~cd}$ & $2.1 \mathrm{~b}$ & $7.8 \mathrm{a}$ & $4.6 \mathrm{a}$ & $4.0 \mathrm{~A}$ \\
\hline Но95-988 & $7.2 \mathrm{a}$ & $6.0 \mathrm{a}$ & $1.5 \mathrm{c}$ & $0.7 \mathrm{~cd}$ & $3.8 \mathrm{~A}$ \\
\hline НоСР96-540 & $1.6 \mathrm{bcd}$ & $1.8 \mathrm{bc}$ & $4.6 \mathrm{~b}$ & $3.1 \mathrm{ab}$ & $2.8 \mathrm{~A}$ \\
\hline L99-226 & $2.5 \mathrm{bc}$ & $2.7 \mathrm{~b}$ & $3.9 \mathrm{~b}$ & $2.2 \mathrm{bc}$ & $2.8 \mathrm{~A}$ \\
\hline L99-233 & $2.8 \mathrm{~b}$ & $1.4 \mathrm{bc}$ & $0.4 \mathrm{c}$ & $0.4 \mathrm{~cd}$ & $1.1 \mathrm{~B}$ \\
\hline L01-283 & $1.5 \mathrm{~cd}$ & $0.1 \mathrm{c}$ & $1.1 \mathrm{c}$ & $0.1 \mathrm{~d}$ & $0.7 \mathrm{C}$ \\
\hline L01-299 & $0.5 \mathrm{~d}$ & $0.1 \mathrm{c}$ & $0.5 \mathrm{c}$ & $0.1 \mathrm{~d}$ & $0.3 \mathrm{C}$ \\
\hline Mean & $2.5 \mathrm{~A}$ & $2.0 \mathrm{~A}$ & $2.8 \mathrm{~A}$ & $1.6 \mathrm{~A}$ & $\ldots$ \\
\hline
\end{tabular}

z Number of lesions per square centimeter of leaf following inoculation with each of four urediniospore collections. The cultivar from which spores were collected is shown in parentheses; there were two different spore collections from Ho 95-988. Cultivar means within a column followed by different lowercase letters were significantly different and overall means within spore collections and across cultivars followed by different uppercase letters were significantly different as determined by Fisher's least significant difference test $(P=0.05)$.

Table 4. Comparison of infection severity assessed as lesion density in seven sugarcane cultivars resulting from inoculation under controlled conditions with four Puccinia melanocephala urediniospore collections from three cultivars from experiment 2

\begin{tabular}{|c|c|c|c|c|c|}
\hline \multirow[b]{2}{*}{ Cultivar inoculated } & \multicolumn{5}{|c|}{ Lesion density for four urediniospore collections ${ }^{\mathrm{z}}$} \\
\hline & Collection 1 (Ho95-988-1) & Collection 2 (Ho95-988-2) & Collection 3 (HoCP96-540) & Collection 4 (L99-226) & Mean \\
\hline LCP85-384 & $3.6 \mathrm{~b}$ & $1.7 \mathrm{~d}$ & $4.5 \mathrm{ab}$ & $1.0 \mathrm{ab}$ & 2.7 BCD \\
\hline Ho95-988 & $6.8 \mathrm{a}$ & $9.5 \mathrm{a}$ & $10.8 \mathrm{a}$ & $1.1 \mathrm{a}$ & $7.0 \mathrm{~A}$ \\
\hline НоСР96-540 & $7.1 \mathrm{a}$ & $5.8 \mathrm{bc}$ & $7.5 \mathrm{ab}$ & $0.4 \mathrm{abc}$ & $5.2 \mathrm{AB}$ \\
\hline L99-226 & $3.5 \mathrm{~b}$ & $7.0 \mathrm{ab}$ & $6.5 \mathrm{ab}$ & $1.0 \mathrm{a}$ & $4.5 \mathrm{BC}$ \\
\hline L99-233 & $1.6 \mathrm{bc}$ & $2.5 \mathrm{~cd}$ & $4.8 \mathrm{ab}$ & $0.1 \mathrm{c}$ & $2.2 \mathrm{CD}$ \\
\hline L01-283 & $0.5 \mathrm{c}$ & $0.6 \mathrm{~d}$ & $2.2 \mathrm{~b}$ & $0.3 \mathrm{bc}$ & $0.9 \mathrm{D}$ \\
\hline L01-299 & $0.4 \mathrm{c}$ & $0.2 \mathrm{~d}$ & $0.9 \mathrm{c}$ & $0.1 \mathrm{c}$ & $0.4 \mathrm{D}$ \\
\hline Mean & $3.3 \mathrm{~A}$ & $3.9 \mathrm{~A}$ & $5.3 \mathrm{~A}$ & $0.6 \mathrm{~B}$ & $\ldots$ \\
\hline
\end{tabular}

z Number of lesions per square centimeter of leaf following inoculation with each of four urediniospore collections. The cultivar from which spores were collected is shown in parentheses; there were two different spore collections from Ho 95-988. Cultivar means within a column followed by different lowercase letters were significantly different and overall means within spore collections and across cultivars followed by different uppercase letters were significantly different as determined by Fisher's least significant difference test $(P=0.05)$. 
Lower infection severity for two of the three traits assessed occurred in the second experiment, conducted in December. In a previous study to determine the effects of temperature and leaf wetness on infection by $P$. melanocephala (3), lower severity assessed as percent leaf area occurred in a repeat experiment conducted in December. Reduced light quantity during the preinoculation period of plant growth has been shown to result in lower infection for two other Puccinia spp., P. striiformis and $P$. triticina (23).

Phenotyping sugarcane clone resistance reactions based on natural infection in the field is affected by uncontrolled inoculum exposure and variable environmental conditions. Inoculation under controlled conditions has potential for use as a research tool to study resistance to brown rust. However, there is a limitation on the number of clones that can be inoculated, and some variability is evident in the results with the current method. Further research is needed to determine the potential applications of inoculation under controlled conditions for the evaluation of brown rust resistance.

The genetics of the host-pathogen interaction is still incompletely understood for brown rust. The occurrence of quantitative resistance to brown rust was demonstrated in this study. The moderate disease severity resulting from inoculation with all urediniospore collections and the lower severity of disease consistent across cultivars inoculated with the L 99-226 collection suggest that this cultivar may have a low, potentially ineffective level of quantitative resistance. Field observations support this interpretation. In the field, the onset of the brown rust epidemic is delayed and severity is erratic in L 99-226 compared with the other susceptible cultivars (J. W. Hoy, unpublished). Potentially, the most important result of this study was the low levels of disease documented in brown-rust-resistant L 99-233 after inoculation with all urediniospore collections under conditions very favorable for infection. The response suggests that this cultivar possesses a high level of quantitative resistance. L 99-233 has remained resistant to brown rust while under commercial cultivation. The maximum area under cultivation with L 99-233 was only 11\% (9); therefore, lower selection pressure on the pathogen population could have accounted for the persistence of resistance, because the other cultivars that became susceptible over time (LCP 85-384, HoCP 96540, and L 99-226) had maximum cultivation areas of 91, 50, and $21 \%$, respectively. However, Ho 95-988 that rapidly became highly susceptible to brown rust was never grown on more than $5 \%$ of the production area.

L 01-299 is the only commercial cultivar in Louisiana that contains Bru1, a major brown rust resistance gene (13), and it exhibited very little disease regardless of urediniospore source. The nature of the high level of resistance recorded in L 01-283 is uncertain. There have been recent observations of high infection levels of brown rust in multiple fields of this cultivar (J. W. Hoy, unpublished). It was grown on 11\% of the production area in 2012 (9) and is still increasing in production area. This suggests that a marked change from resistance to susceptibility is occurring, and brown rust resistance in L 01-283 is not strongly quantitative in nature.

The study results confirmed pathogenic variability in $P$. melanocephala related to host genotype or cultivar. The lack of resistance durability has been a problem with brown rust, a sugarcane disease that has been unpredictable and intractable due to incomplete understanding of the host-pathogen genetics. The quantitative resistance detected in L 99-233 could be very useful in ongoing resistance research. An understanding of the molecular genetics of the L 99-233 disease response could lead to the development of markers that, combined with markers for the known resistance gene Bru1 (4), could improve breeding and selection for highly effective and durable resistance to brown rust.

\section{Acknowledgments}

We thank C. Savario for expert technical assistance. The research would not have been possible without funding provided by the American Sugar Cane League.

Table 5. Comparison of infection severity assessed as individual leaf area in seven sugarcane cultivars resulting from inoculation under controlled conditions with four Puccinia melanocephala urediniospore collections from three cultivars from experiment 1

\begin{tabular}{|c|c|c|c|c|c|}
\hline \multirow[b]{2}{*}{ Cultivar inoculated } & \multicolumn{5}{|c|}{ Leaf area for four urediniospore collections $\left(\mathrm{mm}^{2}\right)^{\mathrm{z}}$} \\
\hline & Collection 1 (Ho95-988-1) & Collection 2 (Ho95-988-2) & Collection 3 (HoCP96-540) & Collection 4 (L99-226) & Mean \\
\hline LCP85-384 & $0.5 \mathrm{~b}$ & $0.7 \mathrm{bc}$ & $1.2 \mathrm{a}$ & $0.5 \mathrm{a}$ & $0.7 \mathrm{AB}$ \\
\hline Но95-988 & $1.2 \mathrm{a}$ & $1.3 \mathrm{a}$ & $0.4 \mathrm{~b}$ & $0.4 \mathrm{a}$ & $0.8 \mathrm{~A}$ \\
\hline НоСР96-540 & $0.4 \mathrm{~b}$ & $0.4 \mathrm{c}$ & $0.6 \mathrm{ab}$ & $0.8 \mathrm{a}$ & $0.6 \mathrm{AB}$ \\
\hline L99-226 & $0.4 \mathrm{~b}$ & $0.5 \mathrm{c}$ & $0.6 \mathrm{ab}$ & $0.5 \mathrm{a}$ & $0.5 \mathrm{~B}$ \\
\hline L99-233 & $0.5 \mathrm{~b}$ & $0.4 \mathrm{c}$ & $0.5 \mathrm{~b}$ & $0.8 \mathrm{a}$ & $0.5 \mathrm{~B}$ \\
\hline L01-283 & $0.4 \mathrm{~b}$ & $0.5 \mathrm{c}$ & $0.5 \mathrm{~b}$ & $0.8 \mathrm{a}$ & $0.5 \mathrm{~B}$ \\
\hline L01-299 & $0.4 \mathrm{~b}$ & $1.0 \mathrm{ab}$ & $0.7 \mathrm{ab}$ & $0.5 \mathrm{a}$ & $0.7 \mathrm{AB}$ \\
\hline Mean & $0.5 \mathrm{~A}$ & $0.7 \mathrm{~A}$ & $0.7 \mathrm{~A}$ & $0.6 \mathrm{~A}$ & $\ldots$ \\
\hline
\end{tabular}

${ }^{\mathrm{z}}$ Individual leaf area following inoculation with each of four urediniospore collections. The cultivar from which spores were collected is shown in parentheses; there were two different spore collections from Ho 95-988. Cultivar means within a column followed by different lowercase letters were significantly different and overall means within spore collections and across cultivars followed by different uppercase letters were not significantly different as determined by Fisher's least significant difference test $(P=0.05)$.

Table 6. Comparison of infection severity assessed as individual leaf area in seven sugarcane cultivars resulting from inoculation under controlled conditions with four Puccinia melanocephala urediniospore collections from three cultivars from experiment 2

\begin{tabular}{|c|c|c|c|c|c|}
\hline \multirow[b]{2}{*}{ Cultivar inoculated } & \multicolumn{5}{|c|}{ Leaf area for four urediniospore collections $\left(\mathrm{mm}^{2}\right)^{\mathrm{z}}$} \\
\hline & Collection 1 (Ho95-988-1) & Collection 2 (Ho95-988-2) & Collection 3 (HoCP96-540) & Collection 4 (L99-226) & Mean \\
\hline LCP85-384 & $0.9 \mathrm{c}$ & $0.8 \mathrm{a}$ & $0.2 \mathrm{~b}$ & $0.4 \mathrm{~b}$ & $0.4 \mathrm{AB}$ \\
\hline Но95-988 & $1.7 \mathrm{a}$ & $0.4 \mathrm{a}$ & $0.2 \mathrm{~b}$ & $0.1 \mathrm{~b}$ & $0.2 \mathrm{AB}$ \\
\hline НоСР96-540 & $1.7 \mathrm{a}$ & $0.2 \mathrm{a}$ & $0.4 \mathrm{a}$ & $0.3 \mathrm{~b}$ & $0.3 \mathrm{AB}$ \\
\hline L99-226 & $1.9 \mathrm{a}$ & $0.2 \mathrm{a}$ & $0.3 \mathrm{~b}$ & $0.2 \mathrm{~b}$ & $0.2 \mathrm{AB}$ \\
\hline L99-233 & $1.0 \mathrm{c}$ & $0.1 \mathrm{a}$ & $0.2 \mathrm{~b}$ & $1.4 \mathrm{a}$ & $0.5 \mathrm{~A}$ \\
\hline L01-283 & $1.2 \mathrm{bc}$ & $0.1 \mathrm{a}$ & $0.1 \mathrm{~b}$ & $0.1 \mathrm{~b}$ & $0.1 \mathrm{~B}$ \\
\hline L01-299 & $1.5 \mathrm{abc}$ & $0.2 \mathrm{a}$ & $0.2 \mathrm{~b}$ & $0.4 \mathrm{~b}$ & $0.2 \mathrm{AB}$ \\
\hline Mean & $0.1 \mathrm{~B}$ & $0.3 \mathrm{AB}$ & $0.2 \mathrm{~B}$ & $0.4 \mathrm{~A}$ & $\ldots$ \\
\hline
\end{tabular}

${ }^{\mathrm{z}}$ Individual leaf area following inoculation with each of four urediniospore collections. The cultivar from which spores were collected is shown in parentheses; there were two different spore collections from Ho 95-988. Cultivar means within a column followed by different lowercase letters were significantly different and overall means within spore collections and across cultivars followed by different uppercase letters were significantly different as determined by Fisher's least significant difference test $(P=0.05)$. 


\section{Literature Cited}

1. Asnaghi, C., D’Hont, A., Glaszmann, J. C., and Rott, P. 2001. Resistance of sugarcane cultivar R570 to Puccinia melanocephala isolates from different geographic locations. Plant Dis. 85:282-286.

2. Avellaneda, M. C., Hoy, J. W., and Pontif, M. P. 2013. Seedling inoculation for cross appraisal of brown rust resistance. (Abstr.) J. Am. Soc. Sugar Cane Technol. 33:55-56.

3. Barrera, W., Hoy, J., and Li, B. 2012. Temperature and leaf wetness effects on infection of sugarcane by Puccinia melanocephala. J. Phytopathol. 160:294-298.

4. Costet, L., Le Cunff, L., Royaert, S., Raboin, L.-M., Hervouet, C., Toubi, L., Telismart, H., Garsmeur, O., Rousselle, Y., Pauquet, J. Nibouche, S., Glaszmann, J.-C., Hoarau, J.-Y., and D'Hont, A. 2012. Haplotype structure around Bru1 reveals a narrow genetic basis for brown rust resistance in modern sugarcane cultivars. Theor. Appl. Genet. 125:825-836.

5. Daugrois, J. H., Grivet, L., Roques, D., Hoarau, J. Y., Lombard, H., Glaszmann, J. C., and D'Hont, A. 1996. A putative major gene for rust resistance linked with a RFLP marker in sugarcane cultivar R570. Theor. Appl. Genet. 92:1059-1064.

6. Dean, J. L., and Purdy, L. H. 1984. Races of sugarcane rust fungus, Puccinia melanocephala, found in Florida. Sugar Cane 1984:15-16.

7. D'Hont, A., Grivet, L., Feldmann, P., Glaszmann, J. C., Rao, S., and Berding, N. 1996. Characterisation of the double genome structure of modern sugarcane cultivars (Saccharum spp.) by molecular cytogenetics. Mol. Gen. Genet. 250:405-413.

8. Glynn, N. C., Laborde, C., Davidson, R. W., Irey, M. S., Glaz, B., D’Hont, A., and Comstock, J. C. 2013. Utilization of a major brown rust resistance gene in sugarcane breeding. Mol. Breed. 31:323-331.

9. Gravois, K. A., and Legendre, B. L. 2013. The 2012 Louisiana sugarcane variety survey. Sugar Bull. 91:21-25.

10. Hogarth, D. M., Ryan, C. C., and Taylor, P. W. J. 1993. Quantitative inheritance of rust resistance in sugarcane. Field Crops Res. 34:187-193.

11. Hoy, J. W., and Grisham, M. P. 2005. Impact of rust on LCP 85-384. Sugar Bull. 845:12-13.

12. McIntyre, C. L., Casu, R. E., Drenth, J., Knight, D., Whan, V. A., Croft, B.
J., Jordan, D. R., and Manners, J. M., 2005. Resistance gene analogues in sorghum and sugarcane and their association with quantitative trait loci for rust resistance. Genome 48:391-400.

13. Parco, A. Hale, A., Kimbeng, C., Hoy, J., and Baisakh, N. 2013. Frequency of brown rust resistance gene Bru1 in the germplasm collection of the Louisiana sugarcane breeding program. (Abstr.) J. Am. Soc. Sugar Cane Technol. 33:77-78.

14. Piperidis, G., and D'Hont, A. 2001. Chromosome composition analysis of various Saccharum interspecific hybrids by genomic in situ hybridisation (GISH). Proc. Int. Soc. Sugar Cane Technol. 24:565-566.

15. Purdy, L. H., Liu, L.-J., and Dean, J. L. 1983. Sugarcane rust, a newly important disease. Plant Dis. 67:1292-1296.

16. Raboin, L., Oliveira, K., Le Cunff, L., Telismart, H., Roques, D., Butterfield, M., Hoarau, J. Y., and D'Hont, A. 2006. Genetic mapping in sugarcane, a high polyploidy, using bi-parental progeny: Identification of a gene controlling stalk colour and a new rust resistance gene. Theor. Appl. Genet. 112:1382-1391.

17. Raid, R. N. 1989. Physiological specialization in sugarcane rust (Puccinia melanocephala) in Florida. Plant Dis. 73:183.

18. Raid, R. N., and Comstock, J. C. 2000. Common rust. Pages 85-89 in: A Guide to Sugarcane Diseases. P. Rott, R. A. Bailey, J. C. Comstock, B. J. Croft, and A. S. Saumtally, eds. CIRAD and ISSCT.

19. Shine, J. M., Jr., Comstock, J. C., and Dean, J. L. 2005. Comparison of five isolates of sugarcane brown rust and differential reaction on six sugarcane clones. Sugar Cane Int. 23:24-29, 36.

20. Srinivasan, K. V., and Muthaiyan, M. C. 1965. A note on physiological races of Puccinia erianthi Padw. \& Khan affecting sugarcane varieties. Proc. Int. Soc. Sugar Cane Technol. 12:1126-1128.

21. Tai, P. Y. P., Miller, J. D., and Dean, J. L. 1981. Inheritance of resistance to rust in sugarcane. Field Crops Res. 4:261-268.

22. Taylor, P. W. J. 1992. Evidence for the existence of a single race of common rust caused by Puccinia melanocephala, in Australian sugar cane cultivars. Aust. J. Agric. Res. 43:443-450.

23. Vallavielle-Pope, C., Huber, L., Leconte, M., and Bethenod, O. 2002. Preinoculation effects of light quantity on infection efficiency of Puccinia striiformis and P. triticina on wheat seedlings. Phytopathology 92:1308-1314. 